\title{
MEADOW VEGETATION OF THE ZHETYSU ALATAU MOUNTAINS
}

\author{
DIMEYEVA, L. A. ${ }^{*}{ }^{*}$ SITPAYEVA, G. T. ${ }^{1}-$ USSEN, K. ${ }^{2}-$ ORLOVSKY, L. $^{3}-$ \\ ABLAIKHANOV, E. ${ }^{4}$ - ISLAMGULOVA, A. F. ${ }^{1}-$ ZHANG, Y. ${ }^{5}-$ ZHANG, J. $^{5}-$ \\ SULEIMENOVA, N. S. ${ }^{2}$ \\ ${ }^{1}$ Institute of Botany and Phytointroduction, Almaty, 050040, Kazakhstan \\ ${ }^{2}$ Department of Ecology, Kazakh National Agrarian University, Almaty, Kazakhstan \\ ${ }^{3}$ Ben-Gurion University of Negev, Sede Boqer, Israel \\ ${ }^{4}$ Al-Farabi Kazakh National University, Almaty, Kazakhstan \\ ${ }^{5}$ Xinjiang Institute of Ecology and Geography, Chinese Academy of Sciences, Urumqi, China \\ *Corresponding author \\ e-mail: l.dimeyeva@mail.ru \\ (phone: +7-727-3947642, fax: +7-727-3948040) \\ (Received 28 $8^{\text {th }}$ Apr 2016; accepted $22^{\text {nd }}$ Jul 2016)
}

\begin{abstract}
The Zhetysu (Junggar) Alatau mountain system consists of mainly two parallel, high mountain ranges: the northern and the southern. The natural border between the ranges is the Koksu river and the Boro Tala river (located in China). Climate conditions, water resources, soil cover, altitudinal zonality of plant cover vary in the northern and the southern ranges (macro slopes). The aim of the research was to give phytocoenotic characteristic of meadow vegetation, to determine the ecological-physiognomic types of meadows, to identify the species composition of natural communities and indicators of anthropogenic influence. Meadow vegetation inhabits a wide altitudinal range from piedmont deserts and low-hill terrains to subalpine and alpine belts, with a high degree of species and phytocoenotic diversity. According to ecological-physiognomic classification, 6 vegetation types of meadows are found in the Zhetysu Alatau Mountains: halophytic on meadow-serozem saline soils, flood-plain-valley (forb-grass typical, grass-forb on floodplain meadow and meadow-chernozem soils; swamp meadows on paludalmeadow soils), steppe on meadow-chernozem and meadow-kastanozem soils, mid-mountain rich grassforb on ordinary and leached chernozems, high-mountain subalpine on mountain-meadow subalpine turf soils, high-mountain alpine on mountain-meadow alpine turf soils. The meadows of the northern range are most diverse, those of the southern, more arid one, are fragmentary. Meadow vegetation is mostly used for grazing and haying, sometimes for tillage. Oftentimes, river valleys are significantly impacted by recreation. The degree of human-induced degradation is assessed as moderate, with sites of severe degradation of vegetation cover. Within the limits of the "Zhongar Alatau" and "Altyn Emel" National Parks remain natural samples of the Zhetysu Alatau meadow vegetation.
\end{abstract}

Keywords: meadows types, species composition, weed species, land use, conservation

\section{Introduction}

Meadow is grass and forb community of mesophilic and halomesophilic, mostly rhizomatous plants that have the winter break of the growing season (Bykov, 1973). Meadows are subdivided into floodplain (riparian), watershed (mainland) and mountain.

The study of meadow vegetation (grasslands) pays great attention due to their high significance. Grasslands are very important from nature conservation aspects but they have economic importance as well. Therefore it is vital to know the species 
composition of the pastures (Házi et al., 2012). The species richness is influenced by many factors (climatic-topographical and soil-geological variables, land-use history, etc. (Janišová, 2014).

Grime (1973) noted that plant species richness of herbaceous communities should peak at intermediate intensities of management (i.e. grazing, mowing, burning or trampling). Many scientists decide questions which of the methods have less negative impact - mowing or grazing, the best for sustaining biodiversity, preserving the pasture considering nature conservation and economic aspects (Házi et al., 2012).

Low-intensity grazing is often considered a good management technique (and even better than mowing) because it is expected to create small-scale heterogeneity through varying grazing, trampling and defecation patterns of the livestock, which should allow more species to coexist than under the homogenizing regime of mowing (Redecker et al., 2002; Dengler et al, 2014). Research of meadow vegetation cover not only the livestock impact (Házi et al., 2012; Meadow, 2016, etc.), but wild animals as well (Catorci et al, 2016; Gao et al., 2008).

All of this underlines the need for detailed research of meadows and grasslands. Below we provide a brief history of the research of flora and vegetation in the Zhetysu Alatau Mountains. It is important to know, what is studied and what remains to be examined, which tasks should be explored first. We give a characterization for Kazakhstani and Chinese parts of these transboundary mountain ranges.

The first botanist who visited the Zhetysu Alatau in 1840 was A. I. Schrenk. He collected numerous plants that were new for science. In 1876-78 A. E. Regel made considerable collections of plants in the southern range (Rubtsov, 1948). The first survey of vegetation was prepared by Semyonov-Tianshanski during his trip to the Tien Shan Mountains in 1956-1957 (Semyonov-Tianshanski, 1947). A more detailed study of vegetation started already in the $20^{\text {th }}$ century (Shipchinski et al., 1930; Lipshits, 1931; Rodin, 1934; Polyakov, 1941, etc.). The most complete information on vegetation cover is in the classic work of N. Rubtsov (1948). Natural forage lands, seasonal ways of their use were studied by L. N. Sobolev (Sobolev, 1960). A considerable attention was paid to the studies of wild Sievers apple-tree (Jangaliev, 1977). Subsequently, this problem was studied under the Project by GEF-UNDP titled "The Conservation of Mountain Agrobiological Diversity in Kazakhstan", wild fruit (apple tree) grooves were thoroughly studied in the northern range (Wild Fruit Forests of Kazakhstan, 2012, etc.). The description of Schrenk spruce forests with classification of the main forest types and their subdivision into districts was made by B. A. Bykov in his work "The Tien Shan Spruce Forests" (Bykov, 1985). Spatial regularities of plants distribution are reflected in small-scaled maps (Vegetation Map..., 1995; National Atlas, 2010).

Flora of the Zhetysu Alatau Mountains comprises 2168 species of vascular plants belonging to 112 families and 622 genera (Goloskokov, 1984), among which there are 15 species of ferns, 6 - horsetails, 13 - gymnosperm plants, and 2134 species of angiosperms. V. Goloskokov noted a high endemism (76 species) of the flora. In addition, he conducted a botanical and geographical assessment, distinguished the main groups of economically valuable plants. There are 297 forage plant species, 104 officinal, 69 poisonous, 54 etherial and oleiferous, 24 tanniferous, 52 nectariferous, 11 vitaminous, 32 industrial, 133 ornamental plant species, 322 weeds. Besides, V. P. Goloskokov presented 73 plant species that require protection (Adianthum capillusveneris L., Eremurus robustus (Regel) Regel, Allium galanthum Kar. \& Kir., Crocus alatavicus Regel \& Semen., Paeonia hybrida Pall., Adonis tianschanica (Adolf) 
Lipsch., Berberis iliensis M. Pop., Corydalis semenovii Regel, Rhodiola rosea L., Malus sieversii (Ledeb.) M. Roem., Euonimus semenovii Regel \& Herd., Louiseania ulmifolia (Franch.) Pachom., Silaum saxatilis Bajt., Stemmacantha carthamoides (Willd.) M. Dittrich., etc.).

For us it was very interesting to compare research in Kazakhstan with data obtained in China. As the Boundary Mountain between China and Kazakhstan, Alatau Mountain is situated in the northern part of Borotala Mongolia Autonomous Prefecture of Xinjiang and is between the Yili (Ile) river and Alakol Lake. Due to limited precipitation, the southern slope within the territory of China belongs to extreme arid climate. However, moisture from the Atlantic can still enter into windward mountains because they are not too high. As a result, relatively dense forest and meadow vegetation are presented in local areas. In addition, steppe and desert vegetation occupy the southern and eastern mountains areas of lower altitudes (Ma, 2008). Thus, vertical altitude and habitat diversification (from the low to high and from the plain desert to mountain) provide favorable conditions for the development of all types of vegetation, formed a vertical belts characterized by desert, grassland, shrub, forest, meadow and alpine vegetation (Zhao et al., 2013a).

From the perspective of ecological geography and flora distribution, Alatau Mountain locates just in transition zone of Central Asia, Middle Asia and Siberia plant area. Therefore, natural environment has changed over the geological history, which provides some advantages for approaching, mixing and specializing of different floristic elements and makes the flora of this region characterized by polydemic (Hai et al., 2011). Comprehensive surveys and investigations of biological resources have not been well carried out in this region. After reunification of Xiaerxili in 1999, scientific expeditions to Xiaerxili were carried out twice in both 2004 and 2005. The results showed that there were 1680 species of vascular plants (including the subspecies and variants) belonging to 81 families and 517 genera, among which there were 23 species of ferns, 9 species of gymnosperms, and 1648 species of angiosperms (Hai et al., 2011).

In this area, there are orchids including Orchis latifolia L. and Goodyera schlechtendaliana Rchb. f., and there are more than 60 species of State's and Autonomous region's key protected plants, including Astragalus mongholicus Bunge, Saussurea involucrate (Kar. et Kir.) Sch.-Bip, Haloxylon ammodendron (C. A. Mey) Bunge, Glycyrrhiza uralensis Fisch., Cistanche deserticola Ma, Lithospermum erythrorhizon Sieb. et Zucc.; 9 species are endemic plants distributed in this area, including Polystichum alatawshanicum C. Y. Yang, Salix pyrolifolia Ledeb., Delphinium elliptico-ovatum W. T. Wang, Scutellaria orthotricha C. Y. Wu et H. W. Li, Thymus altaicus Klok. Et Shost., Solanum boreali-sinense C. Y. Wu, Seriphidium borotalense (Poljak.) Ling \& Y. R. Ling, Mulgedium alatoicum C. H. An, Iris curvifolia Y. T. Zhao, etc. Besides forest plants and abundant forage plant resources, edible, medicinal, ornamental, fragrant, sand-fixing, nectar, fiber plants were reported from this area (Wang, 2007).

Meanwhile, wild relatives of plant resources are also rich in this area. According to the investigation, there are 188 species of relatives of cultivated plants including 64 species crop wild relatives, 124 species of relatives of cultivated forage grasses in Xiaerxili (Zhao et al., 2013b). Among the relatives of cultivated crops: there are 33 species of wild relatives of wheat and barley, 1 species of wild oat, 2 species of wild millet, 7 species of wild relatives of pea, 6 species of wild relatives of oil crop, 15 species of wild Allium. Among the relatives of forage grass: there are 69 species of 
leguminous forage, 47 species of grasses, and 8 species of Chenopodiaceous forage. These relative plants enrich the gene pool of cultivated crops in China, and increase the genetic diversity of cultivated crops.

From the above it follows that most studied for Kazakhstani and Chinese parts of the mountains are flora, rare and economically valuable plants. Detailed geobotanical studies and descriptions of vegetation types in the Kazakhstani part of the Zhetysu Alatau Mountains were held in the middle of the last century. Therefore, the primary objective was to assess the current state of vegetation cover.

The studies were conducted during the third decade of July in 2014-2015. The studies resulted in articles published on altitudinal belt regularities and vegetation types of the Zhetysu Alatau southern range (Dimeyeva and Ablaikhanov, 2014; Dimeyeva et al., 2015a), steppe vegetation of the Zhetysu Alatau (Dimeyeva et al., 2015b). This work focuses on meadow vegetation, one of the mostly distributed vegetation types in the Zhetysu Alatau Mountains. In face of the predecessors' researches, an inventory making of meadow vegetation is currently of great importance for revealing common regularities of distribution, assessing human-induced loads on natural ecosystems and for developing measures on sustainable utilization.

It is important to note that in the region there are two national parks. The establishment of the "Zhongar Alatau" National Nature Park in 2010 covering 356,000 hectares contributed to the conservation of the unique biological diversity of the northern range. In the southern range exists National Nature Park "Altyn Emel" established in 1996 occupied the area of 520,200 hectares. Botanical survey of the areas was carried out before the opening of the national parks. Currently, monitoring of key species and communities is carried out.

This is the first detailed geobotanical study after a long period of their absence, and for the meadow vegetation it is the first analysis. Each vegetation description entered into the GIS and will be used for the purposes of mapping.

\section{Materials and methods}

\section{Study area}

The Zhetysu Alatau mountain system is located in the eastern part of Kazakhstan, stretching from the west and south-west to the east and north-east along the state frontier of Kazakhstan and China between the Ile river and Alakol lake. In the east the mountains are separated from China-located Barlyk and Miley ridges by the Junggar Gates, in the south the mountains are separated from the Tien Shan northern chains the Ile Alatau and Ketmen ranges by the Ile river valley (Gvozdetskyi and Mikhailov, 1978). The Zhetysu Alatau Mountains are extended in the latitudinal direction along $450 \mathrm{~km}$, and with a width of 100-250 km. The Zhetysu Alatau mountain system consists of several high parallel ranges (generally two, the northern and the southern) (Relief of Kazakhstan, 1991). The longest mountain chain stretches in the north. The natural border between the ranges is the Koksu river (length of $205 \mathrm{~km}$ ) and the Borotala river (length of $250 \mathrm{~km}$, located in China).The southern range has several parallel ridges. It begins as Suuktube and Sarychaban ridges in the west, followed by Toksanbay, Besmainak, Tyshkantau to the east (in the limits of Kazakhstan). The mountains continue in China as Bedzhintau and Boro-Horo ridges. The average height of the mountains is $3770 \mathrm{~m}$ above sea level (a.s.1.).The highest point of the northern range is the Semenov-Tianshanski (Besbaskan) mountain (4662 $\mathrm{m}$ a.s.l.), the Panfilov 
(Ormekshi) mountain (4359 $\mathrm{m}$ a.s.1.) is the highest point of the southern range. The snow line is at the height of $3200-3800 \mathrm{~m}$ a.s.l. The area of glacier covering is about 1000 square kms. The glacierization in the northern slope is more than in the southern one. The number of glaciers is over 1,000. The glaciers are for the most part in the stage of contraction. There are traces of two ancient glaciations. The largest Voeikov glacier is located in the upper stream of the Chizhin river. Its length is $8.6 \mathrm{~km}$.

The climate is continental. It is characterized by considerable solar insolation, dry and warm summer, cold winter with low snow in the foothills, frequent temperature inversions and grate snow cover in the mountains (Gvozdetskyi and Mikhailov, 1978).

Average annual climate data are taken from several meteorological stations located in southern range (Zharkent, at an elevation of $643 \mathrm{~m}$ a.s.l., Kugaly, $1410 \mathrm{~m}$ a.s.l.), in the northern range - Lepsy, $1012 \mathrm{~m}$ a.s.1.; Tekely, $1722 \mathrm{~m}$ a.s.l. (Reference Book..., $2004 \mathrm{a} ; 2004 \mathrm{~b})$. Average annual air temperature varies from $1.3-4.8^{\circ} \mathrm{C}$ in intermountain valleys (Lepsy, Kugaly, Tekely) to $9.3^{\circ} \mathrm{C}$ in foothills (Table 1); average annual precipitation amount varies from $184-520 \mathrm{~mm}$ in the southern range to $697-831 \mathrm{~mm}$ in the northern range (Table 2); numbers of frost-free days are as follows: Zharkent -183 , Kugaly - 123, Lepsy - 97, Tekely - 128 .

Table 1. Average monthly air temperature $\left({ }^{\circ} \mathrm{C}\right)$ in meteorological stations of the Zhetysu Alatau Mountains

\begin{tabular}{c|c|c|c|c|c|c|c|c|c|c|c|c|c}
\hline Station & I & II & III & IV & V & VI & VII & VIII & IX & X & XI & XII & Mean \\
\hline Zharkent & -8.9 & -5.7 & 3.5 & 12.8 & 18.1 & 22.2 & 24.0 & 22.8 & 17.4 & 9.9 & 0.9 & -5.9 & 9.3 \\
\hline Kugaly & -8.8 & -7.8 & -2.7 & 6.1 & 11.5 & 15.4 & 17.7 & 17.0 & 12.4 & 5.6 & -2.5 & -6.6 & 4.8 \\
\hline Lepsy & -17.6 & -14.9 & -6.5 & 4.9 & 11.5 & 15.6 & 17.5 & 15.9 & 10.7 & 3.5 & -7.5 & -14.7 & 1.5 \\
\hline Tekely & -6.4 & -5.6 & -1.5 & 5.5 & 10.0 & 14.0 & 16.1 & 15.5 & 11.0 & 4.8 & -1.1 & -4.2 & 4.8 \\
\hline
\end{tabular}

Table 2. Average monthly precipitation amount $(\mathrm{mm})$ in meteorological stations of the Zhetysu Alatau Mountains

\begin{tabular}{c|c|c|c|c|c|c|c|c|c|c|c|c|c}
\hline Station & I & II & III & IV & V & VI & VII & VIII & IX & X & XI & XII & Annual \\
\hline Zharkent & 12 & 11 & 13 & 17 & 20 & 24 & 22 & 12 & 11 & 13 & 16 & 13 & 184 \\
\hline Kugaly & 29 & 26 & 36 & 54 & 67 & 64 & 53 & 29 & 27 & 45 & 51 & 39 & 520 \\
\hline Lepsy & 39 & 37 & 54 & 78 & 87 & 68 & 61 & 40 & 37 & 66 & 75 & 55 & 697 \\
\hline Tekely & 39 & 35 & 62 & 92 & 114 & 96 & 90 & 45 & 48 & 81 & 75 & 54 & 831 \\
\hline
\end{tabular}

Surface water resources are abundant (Lvovich, 1984). Most of rivers belong to the Balkhash lake basin: the Horgos, Koksu, Lepsy, Karatal, Usek, Sarkan, Tyshkan, Borohudzir, etc. Some of the rivers belong to the Alakol-Sasykkol lakes basin: Tentek, Tastau. There are no big rivers in the Zhetysu Alatau Mountains with large watershed area (with the exception of the Lepsy river), their total water content is not great. However, due to the large amount of precipitation in mountainous areas, specific stream flow rate attains large values. By the type of hydrological regime, most of the rivers belong to streams with spring-summer seasonal flood, with maximal discharges falling at snow cover melting in spring and at the account of glacier-derived nourishment of rivers in summer.

In soil cover distribution by altitudinal belts, the vertical zonation reveals itself differently in the northern and southern ranges (Sokolov et al., 1978; 1991). Above alpine belt the soil cover is not developed. In the alpine belt, at altitudes of 2000-4000 
a.s.l. at the northern range and 2350-3500 $\mathrm{m}$ a.s.l. at the southern range, dominate Lethic Leptosols according to FAO classification (FAO..., 1997). Podzoluvisols are spread at the height of 1700-2300 m a.s.l. at the northern range. The southern range almost does not completely represent Podzoluvisols, as well as a forest belt. The steppe types of soils climb into the high mountains in the southern range. Phaerozems are distributed at altitudes of 1200-2400 m a.s.l. under high-mountain meadow steppe and meadows in the southern range, and 1000-2200 m a.s.1. Petric and Luvic Calcisols occupy semi-desert low-mountain belt. Carbic Kastanozems and Chernozems are spread in mid-mountains; Fluvosols - along rivers and streams.

According to Botanical-geographic regionalization the Zhetysu Alatau Mountains belong to Junggar-North Tien Shan mountain botanical-geographic province (Rachkovskaya et al., 2003).

The features of altitudinal plant zonality are different in the northern and southern ranges (Rachkovskaya et al., 2003; Dimeyeva and Ablaikhanov, 2014). The altitudinal belts of the northern range: the belt of piedmont deserts (600-800 $\mathrm{m}$ a.s.1.); the steppe belt with sub-belts of desert steppes (800-1000 m a.s.1.), fragments of true steppes $(1000-1200 \mathrm{~m})$, and meadow steppes (1200-1700 m a.s.l.); the belt of small-leaved forests (1400-1700 $\mathrm{m}$ a.s.1.), the belt of dark coniferous forests and meadows (1700$2300 \mathrm{~m}$ a.s.1.); the belt of sub-alpine meadows, steppes and elfin woods $(2300-2800 \mathrm{~m}$ a.s.1.); the belt of cryophytic (alpine) meadows (2800-3300 $\mathrm{m}$ a.s.1.). The altitudinal belts of the southern range: the belt of piedmont deserts (600-800 $\mathrm{m}$ a.s.l.); the steppe belt with sub-belts desert steppes (800-1500 m a.s.1.), and meadow steppes (1500-1700 $\mathrm{m}$ a.s.1.); the forest-meadow belt (1700-2400 $\mathrm{m}$ a.s.1.); the belt of sub-alpine meadows, steppes and elfin woods (2200-2800 m a.s.1.); the belt of cryophytic (alpine) meadows and steppes (2800-3500 $\mathrm{m}$ a.s.1.).

Routes in the Zhetysu Alatau covered: foothill plains, valleys of the rivers Lepsy, Tentek with tributaries; the rivers Sarkan, Terekty, Baskan, Tyshkan, Usek, Koksu, Borohudzir; Lepsy intermountain valley, low mountains Ortatau, Atyzhek, Malaisary; the northern range; the mountain ridges of southern range: Toksanbay, Tyshkantau, Altyn Emel, Orikty, Tulkili, Matai; gorges Sulymatai, Uzynbulak; areas of groundwater runoff Mynbulak, Dongelekbastau and Kolbastau in piedmont valleys (Fig. 1). List of Sample areas are in Appendix 1.

We investigated all altitudinal belts except alpine, which we present according to Rubtzov, 1948; Goloskokov, 1984; Rachkovskaya et al., 2003.

\section{Methods}

The study on vegetation was carried out using traditional methods of field geobotany (Bykov, 1978; Field Geobotany, 1959-1976) including description of main plant communities of the research areas and landscape-ecological profiling. Collection of herbarium specimens was conducted simultaneously with the study of vegetation cover in all habitats. The Vegetation Description Form was used to record vegetative and environmental characteristics of the 100 sq. m sample plots. The form included the following information: GPS coordinates, elevation, topography, soil type, percent cover, species list, abundance by Drude scale (Drude, 1913; Bykov, 1978), degree and type of disturbance, etc. Symbols of Drude's scale indicate frequency of occurrence/coverage of a species. The symbols are as follows: soc (socialis) - the dominant species, frequency of occurrence/coverage exceeds $90 \%$; $\operatorname{cop}_{3}$ (copiosus) - an abundant species, frequency of occurrence/coverage is up to $80 \%$; $\mathrm{cop}_{2}-$ a species is represented by numerous 
individuals, frequency of occurrence/coverage is up to $20 \%$; $\operatorname{cop}_{1}$ - frequency of occurrence/coverage is up to $4 \%$; sp (sparsus) - frequency of occurrence/coverage about $0.8 \%$; sol (solitarus) - scanty individuals, frequency of occurrence/coverage not exceeds $0.16 \%$; un (unicum) - a single individual.

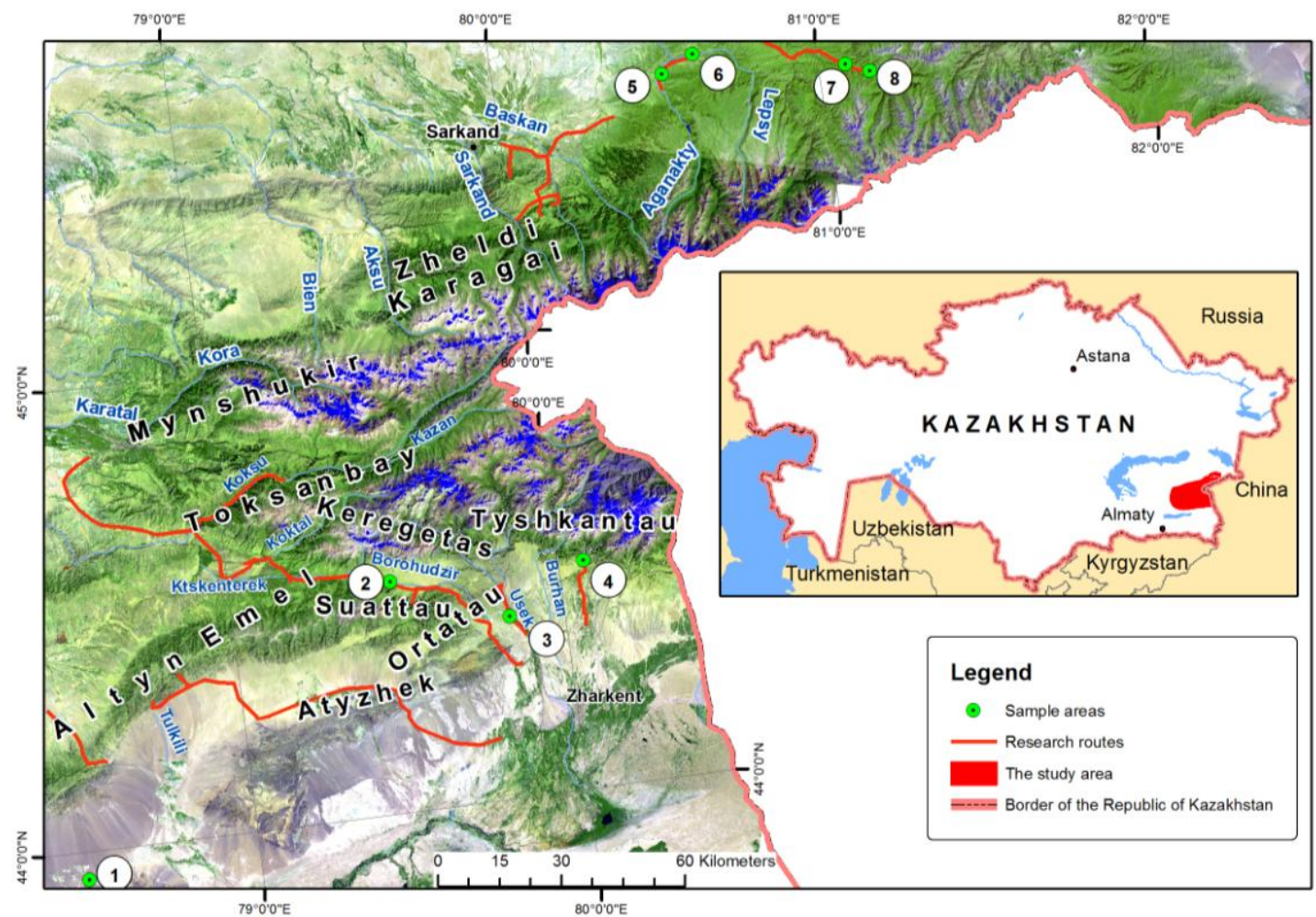

Figure 1. The study area

Types of meadow vegetation have been identified according to ecologicalphysiognomic classification principals (Ellenberg and Mueller-Dombois, 1967; Ellenberg, 1973; Küchler, 1949; 1967; Rachkovskaya et al., 2003, etc.). Ecologicalphysiognomic categories unite communities with species of similar ecology, the same seasonal character of growth and functional (adaptive) features (Rachkovskaya et al., 2003). For description of each ecological-physiognomic type we analyzed at least five Vegetation Description Forms. To determine the types of meadows we used the data from our field studies and compared them with the published ones (Novikova, 1997; Ogar, 1999; 2003). Soils, species composition, and dominant plant species were identified for each type of meadows.

Identification of plants was conducted using the 9-volume "Flora of Kazakhstan" (1956-1976) and taxonomic revision of species names developed by S. Cherepanov (1995). The source of plant names of Chinese part of the mountains was "Flora of China”. Soil types are presented on Sokolov et al. $(1978 ; 1991)$ according to Russian classification system. 


\section{Results}

Meadow vegetation occupies a wide altitudinal range from piedmont deserts and low mountains to subalpine and alpine belts.

In the belt of piedmont deserts, meadows are found in depressions with groundwater runoff (Achnatherum splendens (Trin.) Nevski, Phragmites australis (Cav.) Trin. ex Steud., Inula caspica Blum ex Ledeb., Vicia cracca L., Amoria repens (L.) C. Presl, etc.). In the piedmont valley of the Altyn Emel ridge (the southern range) at brook springs, develop dense shrub thickets, halophytic and swamp meadows (Table 3).

Table 3. Species composition of meadows in the areas with groundwater runoff in the piedmont desert belt

\begin{tabular}{|c|c|c|c|}
\hline \multirow{4}{*}{ Species } & \multicolumn{3}{|c|}{ Abundance by Drude scale } \\
\hline & \multicolumn{2}{|c|}{ Halophytic meadow } & \multirow{2}{*}{$\begin{array}{c}\text { Swamp meadow } \\
\text { Dongelekbastau } \\
\text { spring }\end{array}$} \\
\hline & Mynbulak spring & Kolbastau spring & \\
\hline & $680 \mathrm{~m}$ a.s.1. & $730 \mathrm{~m}$ a.s.l. & $732 \mathrm{~m}$ a.s.1. \\
\hline \multicolumn{4}{|c|}{ Shrubs and semishrubs } \\
\hline $\begin{array}{l}\text { Halimodendron halodendron (Pall.) } \\
\text { Voss }\end{array}$ & $\operatorname{cop}_{1}$ & $\operatorname{cop}_{1-2}$ & sol-sp \\
\hline $\begin{array}{l}\text { Trachomitum lancifolium (Russan.) } \\
\text { Pobed. }\end{array}$ & sol & sol & - \\
\hline Nitraria sibirica Pall. & sol & $\mathrm{sp}-\mathrm{cop}_{1}$ & - \\
\hline Rosa beggeriana Schrenk & - & - & sol \\
\hline Berberis iliensis M. Pop. & - & - & sol-sp \\
\hline Suaeda microphylla Pall. & - & sol & - \\
\hline \multicolumn{4}{|c|}{ Herbs } \\
\hline Alhagi pseudalhagi (Bieb.) Fisch. & sp-cop 1 & - & - \\
\hline Glycyrrhiza aspera Pall. & sp-cop 1 & - & - \\
\hline Glycyrrhiza uralensis & - & - & sol \\
\hline Achnatherum splendens & $\mathrm{sp}$ & $\mathrm{sp}-\mathrm{cop}_{1}$ & sol-sp \\
\hline Atriplex tatarica $\mathrm{L}$. & sp-cop 1 & $\mathrm{sp}$ & - \\
\hline Aeluropus littoralis (Gouan) Parl. & $\mathrm{cop}_{1}$ & sol & - \\
\hline Artemisia schrenkiana Ledeb. & sol-sp & - & - \\
\hline Iris sogdiana Bunge & sol & - & $\mathrm{sp}$ \\
\hline $\begin{array}{l}\text { Suaeda heterophylla (Kar. \& Kir.) } \\
\text { Bunge }\end{array}$ & $\mathrm{sp}$ & $\mathrm{sp}$ & sp-cop 1 \\
\hline Phragmites australis & - & sol & $\mathrm{sp}$ \\
\hline Lavatera thuringiaca $\mathrm{L}$. & - & sol & - \\
\hline Leymus angustus (Trin.) Pilg. & - & $\mathrm{sp}$ & - \\
\hline Leymus divaricatus (Drob.) Tzvel. & - & $\mathrm{sp}$ & $\mathrm{cop}_{1}$ \\
\hline Saussurea amara (L.) DC. & - & sol & sol \\
\hline Acroptilon repens (L.) DC. & - & sol & - \\
\hline $\begin{array}{l}\text { Asparagus persicus Fisch. \& C.A. } \\
\text { Mey. ex Bunge }\end{array}$ & - & sol & - \\
\hline Scirpus tabernaemontani C.C. Gmel. & - & - & sol \\
\hline Mentha longifolia (L.) Huds. & - & - & sol \\
\hline Gypsophila perfoliata L. & - & - & sol \\
\hline Total: & 11 & 15 & 13 \\
\hline
\end{tabular}


The species composition of halophytic meadows is represented by liquorice (Glycyrrhiza aspera, G. uralensis), halophytic grasses (Aeluropus littoralis, Leymus divaricatus, L. angustus, Achnatherum splendens), and saltworts (Atriplex tatarica, Suaeda heterophylla, S. microphylla) with sagebrush (Artemisia schrenkiana) and forbs (Saussurea amara, Lavatera thuringiaca). The species composition of swamp meadows includes Iris sogdiana, Scirpus tabernaemontani, Mentha longifolia, Phragmites australis.

In low-mountain area at the steppe belt elevation points, meadows are found in river valleys and in intermountain depressions. Let us consider the meadow vegetation of the Lepsy intermountain valley (the northern range). There, at the altitude from 984 to 1071 $\mathrm{m}$ a.s.l., typical forb-grass and steppe meadows, which are used for the most part for haying. The species composition of plant communities is represented by numerous forage (Festuca valesiaca Gaudin, Medicago falcata L., Elytrigia repens (L.) Nevski, Phleum phleoides (L.) Karst., etc.) and pharmaceutical (Agrimonia asiatica Juz., Origanum vulgare L., Bupleurum aureum Fish. ex Hoffm., Hypericum perforatum L., etc.) plant species (Table 4).

Table 4. Species composition of meadows in the Lepsy intermountain valley

\begin{tabular}{|c|c|c|c|c|c|}
\hline \multirow{3}{*}{ Species } & \multicolumn{5}{|c|}{ Abundance by Drude scale } \\
\hline & $\begin{array}{l}\text { Steppe } \\
\text { meadow }\end{array}$ & $\begin{array}{l}\text { Valley forb- } \\
\text { grass } \\
\text { meadow }\end{array}$ & $\begin{array}{l}\text { Flood-plain } \\
\text { forb-grass } \\
\text { meadow }\end{array}$ & $\begin{array}{l}\text { Valley forb- } \\
\text { grass } \\
\text { meadow }\end{array}$ & $\begin{array}{l}\text { Steppe } \\
\text { meadow }\end{array}$ \\
\hline & $984 \mathrm{~m}$ a.s.1. & $991 \mathrm{~m}$ a.s.l. & $1005 \mathrm{~m}$ a.s.1. & $1029 \mathrm{~m}$ a.s.1. & $1071 \mathrm{~m}$ a.s.1. \\
\hline \multicolumn{6}{|c|}{ Shrubs } \\
\hline Lonicera tatarica $\mathrm{L}$. & - & - & $\mathrm{sp}$ & - & - \\
\hline Rubus caesius L. & - & - & $\mathrm{sp}$ & - & - \\
\hline $\begin{array}{l}\text { Cotoneaster pojarkovae } \\
\text { Zak. }\end{array}$ & - & - & - & sol & sol \\
\hline \multicolumn{6}{|c|}{ Herbs } \\
\hline $\begin{array}{l}\text { Thymus marschallianus } \\
\text { Willd. }\end{array}$ & $\mathrm{sp}$ & - & - & $\mathrm{sp}$ & $\mathrm{sp}$ \\
\hline $\begin{array}{l}\text { Bromus japonicus } \\
\text { Thunb. }\end{array}$ & $\mathrm{sp}$ & - & - & - & - \\
\hline Achillea millefolium $\mathrm{L}$. & sp-cop 1 & $\mathrm{sp}$ & - & sp-cop 1 & - \\
\hline Stipa capillata L. & sol & - & sol & sp-cop 1 & $\operatorname{cop}_{1}$ \\
\hline Festuca valesiaca & $\mathrm{sp}$ & - & sol & - & - \\
\hline Medicago falcata & sol-sp & - & sol & $\mathrm{sp}$ & $\operatorname{cop}_{1}$ \\
\hline Elytrigia repens & $\mathrm{sp}$ & - & - & $\operatorname{cop}_{1-2}$ & - \\
\hline Phleum phleoides & - & $\operatorname{cop}_{1-2}$ & $\operatorname{cop}_{1-2}$ & & - \\
\hline Poa pratensis L. & - & $\mathrm{cop}_{2}$ & - & & - \\
\hline Dactylis glomerata L. & - & $\mathrm{sp}$ & sol & $\mathrm{sp}$ & - \\
\hline Hypericum perforatum & - & sol & - & & sol \\
\hline Trifolium pratense L. & - & sp-cop 1 & - & $\mathrm{sp}$ & - \\
\hline Origanum vulgare & - & $\mathrm{sp}$ & $\mathrm{sp}$ & sol-sp & sol \\
\hline Vicia cracca & - & sol-sp & - & - & - \\
\hline Agrimonia asiatica & - & $\mathrm{sp}$ & sol & - & - \\
\hline $\begin{array}{l}\text { Phalaroides } \\
\text { arundinacea (L.) } \\
\text { Rauschert }\end{array}$ & - & sol-sp & - & - & - \\
\hline Rumex confertus Willd. & - & sol-sp & - & - & - \\
\hline Melilotus albus Medik. & - & - & sol & - & - \\
\hline
\end{tabular}




\begin{tabular}{|c|c|c|c|c|c|}
\hline Bupleurum aureum & - & - & sol & - & - \\
\hline $\begin{array}{l}\text { Ziziphora } \\
\text { clinopodioides Lam. }\end{array}$ & - & - & - & sp-cop 1 & - \\
\hline $\begin{array}{l}\text { Onobrychis arenaria } \\
\text { (Kit.) DC. }\end{array}$ & - & - & - & $\operatorname{cop}_{1}$ & - \\
\hline Salvia deserta Schang. & - & - & - & $\mathrm{sp}$ & sol \\
\hline Galium verum L. & - & - & - & sol & - \\
\hline Nepeta pannonica L. & - & - & - & sp-cop 1 & $\mathrm{sp}$ \\
\hline $\begin{array}{l}\text { Elymus dahuricus } \\
\text { Turcz. ex Griseb }\end{array}$ & - & - & - & $\mathrm{sp}-\mathrm{cop}_{1}$ & - \\
\hline $\begin{array}{l}\text { Bromopsis inermis } \\
\text { (Leyss.) Holub }\end{array}$ & - & - & - & $\mathrm{sp}$ & - \\
\hline Lactuca serriola L. & - & - & - & sol & - \\
\hline $\begin{array}{l}\text { Leymus multicaulis } \\
\text { (Kar. \& Kir.) Tzvel. }\end{array}$ & - & - & - & $\mathrm{sp}$ & - \\
\hline Lavatera thuringiaca & - & - & - & $\mathrm{sp}$ & - \\
\hline Tanacetum vulgare L. & - & - & - & - & sol-sp \\
\hline $\begin{array}{l}\text { Centaurea ruthenica } \\
\text { Lam. }\end{array}$ & - & - & - & - & $\mathrm{sp}$ \\
\hline $\begin{array}{l}\text { Verbascum orientale } \\
\text { (L.) All. }\end{array}$ & - & - & - & - & sp-cop 1 \\
\hline Total: & 7 & 11 & 11 & 19 & 11 \\
\hline
\end{tabular}

We shall consider mid-mountain rich grass-forb meadows using the Seghizbay pass (the northern range) as an example (Table 5).

Table 5. Species composition of mid-mountain rich grass-forb meadows in the Seghizbay pass

\begin{tabular}{|c|c|c|c|}
\hline \multirow{2}{*}{ Species } & \multicolumn{3}{|c|}{ Abundance by Drude scale } \\
\hline & $1665 \mathrm{~m}$ a.s.1. & $1971 \mathrm{~m}$ a.s.l. & $1990 \mathrm{~m}$ a.s.l. \\
\hline \multicolumn{4}{|c|}{ Shrubs } \\
\hline Pentaphylloides fruticosa (L.) O. Schwarz & - & sol & sol \\
\hline Lonicera tatarica & - & - & sol \\
\hline Juniperus pseudosabina Fisch. \& C.A. Mey. & - & - & $\mathrm{sp}\left(\operatorname{cop}_{1-3}\right)$ \\
\hline Cotoneaster pojarkovae & - & - & sol \\
\hline \multicolumn{4}{|c|}{ Herbs } \\
\hline Aconogonon coriarium (Grig.) Sojak & $\mathrm{sp}$ & sol & sol-sp \\
\hline Achillea millefolium & $\mathrm{sp}-\mathrm{cop}_{1}$ & $\mathrm{sp}$ & sol \\
\hline Dactylis glomerata & $\mathrm{sp}$ & $\operatorname{cop}_{2-3}$ & $\mathrm{cop}_{2}$ \\
\hline Fragaria viridis (Duch.) Weston & $\operatorname{sp}\left(\operatorname{cop}_{1}\right)$ & $\operatorname{cop}_{1}$ & - \\
\hline Origanum vulgare & $\mathrm{sp}-\mathrm{cop}_{1}$ & - & $\mathrm{sp}$ \\
\hline Tanacetum vulgare & $\mathrm{sp}$ & $\mathrm{sp}$ & $\mathrm{sp}$ \\
\hline Rumex confertus & $\mathrm{sp}$ & - & - \\
\hline Sanguisorba alpina Bunge & sol & sp-cop 1 & - \\
\hline Trifolium pratense & $\mathrm{sp}$ & $\mathrm{sp}$ & - \\
\hline Lupinaster pentaphyllus Moench & - & sp-cop 1 & $\mathrm{sp}$ \\
\hline Amoria repens (L.) C. Presl & $\mathrm{sp}$ & - & - \\
\hline Vicia cracca & $\mathrm{sp}$ & - & $\mathrm{sp}$ \\
\hline Lathyrus pratensis L. & sol-sp & - & - \\
\hline Aconitum leucostomum Worosch. & sol-sp & - & - \\
\hline
\end{tabular}




\begin{tabular}{|c|c|c|c|}
\hline Aconitum anthoroideum DC. & - & - & sol \\
\hline Galium turkestanicum Pobed. & sol & sol & - \\
\hline Campanula glomerata L. & sol & - & - \\
\hline Geum rivale $\mathrm{L}$. & sol & - & - \\
\hline Plantago major L. & sol & - & - \\
\hline Potentilla asiatica (Th. Wolf) Juz. & sol-sp & - & - \\
\hline Thalictrum minus L. & sp-cop 1 & - & - \\
\hline Stemmacantha carthamoides & - & $\mathrm{sp}$ & $\mathrm{sp}$ \\
\hline Bupleurum aureum & - & $\mathrm{sp}$ & - \\
\hline Artemisia absinthium L. & - & sol & - \\
\hline Artemisia santolinifolia Turcz. ex Bess. & - & sol & - \\
\hline Artemisia dracunculus L. & - & - & sol \\
\hline Allium obliquum L. & - & $\mathrm{sp}$ & $\mathrm{sp}$ \\
\hline Allium caesium Schrenk & - & $\mathrm{sp}$ & $\mathrm{sp}$ \\
\hline Rhodiola linearifolia Boriss. & - & $\mathrm{sp}$ & - \\
\hline Phleum phleoides & - & sol-sp & $\mathrm{sp}$ \\
\hline Solidago virgaurea $\mathrm{L}$. & - & sol & sol \\
\hline Geranium collinum Steph. & - & $\mathrm{sp}$ & $\mathrm{sp}$ \\
\hline Hieracium virosum Pall. & - & $\operatorname{sp}\left(\operatorname{cop}_{1}\right)$ & $\mathrm{sp}$ \\
\hline Hieracium aurantiacum L. & - & - & sol-sp \\
\hline Carex caucasica Stev. & - & $\mathrm{sp}$ & - \\
\hline Bunium setaceum (Schrenk) H. Wolff & - & $\mathrm{sp}-\mathrm{cop}_{1}$ & - \\
\hline Gentiana kirilowii Turcz. & - & sol & sol \\
\hline Veronica spuria L. & - & sol-sp & sol \\
\hline $\begin{array}{l}\text { Eremurus tianshanicus Pazij \&Vved. ex } \\
\text { Golosk. }\end{array}$ & - & sol & sol-sp \\
\hline Thlapsi arvense L. & - & sol & - \\
\hline Heracleum dissectum Ledeb. & - & sol & sol \\
\hline Chamaenerion angustifolium (L.) Scop. & - & - & $\mathrm{sp}$ \\
\hline Ziziphora clinopodioides & - & - & sp-cop 1 \\
\hline $\begin{array}{l}\text { Patrinia intermedia (Hornem.) Roem. \& } \\
\text { Schult. }\end{array}$ & - & - & $\mathrm{sp}$ \\
\hline Alchemilla bungei Juz. & - & - & $\mathrm{sp}$ \\
\hline Sedum hybridum L. & - & - & sol-sp \\
\hline Hypericum perforatum & - & - & sol-sp \\
\hline Dianthus turkestanicus Preobr. & - & - & sol \\
\hline Swertia connata Schrenk & - & - & sol \\
\hline $\begin{array}{l}\text { Seseli schrenkianum (C.A. Mey. ex Schischk.) } \\
\text { M. Pimen \& Sdobnina }\end{array}$ & - & - & sol-sp \\
\hline Total: & 19 & 28 & 34 \\
\hline
\end{tabular}

Meadows are combined with thickets of elfin juniper (Juniperus pseudosabina). The species composition of meadow vegetation is changed depending on the altitude above the sea level. Several species are found at all elevation points (Aconogonon coriarium, Achillea millefolium, Dactylis glomerata, Tanacetum vulgare). Such species as alpine burnet (Sanguisorba alpina), meadow clover (Trifolium pratense), turkestanic bedstraw (Galium turkestanicum) reach up to $1971 \mathrm{~m}$ a.s.l. Other species, such as Lupinaster pentaphyllus, Stemmacantha carthamoides, Allium obliquum, Solidago virgaurea, Gentiana kirilowii are found at an altitude of over $1900 \mathrm{~m}$ a.s.l. The species 
composition of meadow vegetation depends not only on elevation, but also on the environmental conditions. In stony sites sedum (Sedum hybridum) and ziziphora (Ziziphora clinopodioides) are more abundant. Fireweed (Chamaenerion angustifolium) prefers to grow on well-humidified slopes and also can be met in anthropogenous habitats - in places where forest was cut or burnt. The Seghizbay pass highest point is at the elevation of $2200 \mathrm{~m}$ a.s.l., the subalpine belt beginning from that altitude. The vegetation is represented by grass-forb meadows (Hieracium aurantiacum, Alchemilla bungei, Stemmacantha carthamoides, Poa stepposa (Kryl.) Roshev., Dactylis glomerata, Papaver croceum L., Lupinaster pentaphyllus, Veronica spuria, Achillea millefolium, Aconitum anthoroideum, Allium obliquum, etc.).

Meadow vegetation prevails in the high-mountain belt of the northern range. The lower belt is formed by subalpine mid-herb meadows, which in some spots are alternated with the communities of elfin juniper (Juniperus pseudosabina). Mantle Alchemilla bungei, A. retropilosa Juz.) and crane's-bill meadows (Geranium saxatile Kar. \& Kir., G. albiflorum Ledeb.) are most widely distributed. Species composition includes: Pedicularis dolichorhiza Schrenk, Dracocephalum imberbe Bunge, Astragalus alpinus L., Bistorta vivipara (L.) S.F. Gray, etc. An important role in meadow communities is also played by grasses (Phleum phleoides, Alopecurus pratensis L., Helictotrichon pubescens (Huds.) Pilg.). In the alpine belt kobresia (Kobresia capilliformis Ivanova), cryophytic low-herb meadows (Bistorta vivipara, Primula algida Adams, Festuca kryloviana Reverd., Poa alpina L., Viola altaica KerGawl., etc.) are distributed in combination with high-mountain steppes (Festuca valesiaca, Poa stepposa, Helictotrichon tianschanicum (Roshev.) Henrard) and plant groups of rocks and scree debris (Dracocephalum imberbe Bunge, Saussurea glacialis Herd., Rhodiola coccinea (Royle) Boriss., Potentilla biflora Willd. ex Schlecht., Oxygraphis glacialis (Fisch.) Bunge, Trollius altaicus C.A. Mey., etc.) (Goloskokov, 1984; Rubtsov, 1948). Kobresia meadows are typical of smooth hill slopes, frequently confined to ancient moraine deposits. The composition of those meadows has occasional representation of Thalictrum alpinum L., Bistorta vivipara, Festuca kryloviana, Potentilla gelida, Papaver croceum, etc. Low-herb meadows on steep stony slopes have sparse herbage, in the species composition prevail Bistorta vivipara, $B$. elliptica (Willd. ex Spreng.) Kom., Primula algida, Geranium saxatile, Trisetum altaicum Roshev., T. spicatum (L.) K. Richt., Festuca alatavica (St.-Yves) Roshev. (Rubtsov, 1948).

Subalpine meadows of the southern range are combined with steppes (Festuca valesiaca, F. kryloviana, Helictotrichon tianschanicum, H. altaicum Tzvel., Poa stepposa, elfin juniper woodlands (Juniperus pseudosabina) and sparse plant aggregations of rocks and scree debris. Steppe vegetation prevails. In the head of the Borohudzir river meadows are composed of mantle, mantle-bluegrass (Poa апnиa L., Alchemilla sibirica, Geranium albiflorum, Achillea millefolium, Amoria repens, Urtica dioica L., Ranunculus grandifolius C.A. Mey., Aegopodium alpestre Ledeb., Alfredia nivea Kar. \& Kir.), and grass-forb (Alchemilla sibirica Zam., Geranium collinum, $G$. albiflorum, Potentilla gelida, Alopecurus pratensis, Poa pratensis) communities. There are several endemics in species composition: Taraxacum songoricum Schischk., Alchemilla rubens Juz. Transitory communities are often widespread — steppe meadows and meadow steppes with both steppe grasses and forbs (Poa lipskyi Roshev., Phleum phleoides, Festuca coelestis (St.-Yves) V. Krecz. \& Bobr., Alchemilla sibirica, Achillea setacea Waldst. \& Kit.) (Dimeyeva et al., 2015a; 2015b). The upper layer is 
formed by alpine meadows. Cryophytic meadow communities are diverse in composition (Rubtsov, 1948), and most frequently are represented by kobresia-forb communities (Alchemilla retropilosa, Leontopodium fedtschenkoanum Beauverd, Aster alpinus L., Kobresia capilliformis, K. humilis (C.A. Mey. ex Trautv.) Serg.). Sometimes those meadows are steppificated at the expense of high-mountain grasses (Festuca alatavica, Stipa regeliana Hack.). The upper elevation limits are reached by only separate cryophylous species, forming open plant aggregations among stone fields. Those are Sibbaldia tetrandra Bunge, Cerastium lithospermifolium Fisch., Waldheimia tridactylites Kar. \& Kir., etc.

Meadow vegetation of river valleys is most diverse. The Lepsy river of the northern range is the most full-flowing stream. It is formed from the confluence of the Aganakty and Sarymsakty rivers. The Zhalanash mountain area is located in a place of those two rivers' confluence at elevation from 975 to $1072 \mathrm{~m}$ a.s.l. There, in steep southern slopes of the Lepsy river-side grass-forb steppe meadows are spread (Bromopsis inermis, Leymus multicaulis, Vicia cracca, Fragaria viridis, Medicago falcata, Verbascum orientale, Stipa capillata, etc.) with rare species of Paeonia anomala L., Tulipa brachystemon Regel (The Red Data Book, 2014), shrubby grooves (Spiraea hypericifolia L., Lonicera tatarica), groups of Sievers apple-trees (Malus sieversii (Ledeb.) M. Roem.). In river floodplains the tree layer is dominated by birch (Betula pendula Roth), while the shrub layer is formed by willow (Salix viminalis L.) and Myricaria bracteata Royle. Meadows of Zhalanash area are characterized by high species diversity, the composition of plant communities accounting about 40 species (Table 6).

Table 6. Species composition of meadows in the Zhalanash mountain area

\begin{tabular}{|c|c|c|c|}
\hline \multirow{3}{*}{ Species } & \multicolumn{3}{|c|}{ Abundance by Drude scale } \\
\hline & Swamp meadow & $\begin{array}{l}\text { Grass-forb typical } \\
\text { meadow }\end{array}$ & Steppe meadow \\
\hline & $975 \mathrm{~m}$ a.s.1. & $1019 \mathrm{~m}$ a.s.l. & $1072 \mathrm{~m}$ a.s.l. \\
\hline \multicolumn{4}{|c|}{ Trees } \\
\hline Betula pendula & $\mathrm{sp}$ & - & - \\
\hline Malus sieversii & - & sol & $\mathrm{sp}$ \\
\hline Padus avium Mill. & - & un & - \\
\hline \multicolumn{4}{|c|}{ Shrubs } \\
\hline Salix viminalis & sp-cop 1 & - & - \\
\hline Lonicera tatarica & sol & sol & sol-sp \\
\hline Myricaria bracteata & sol-sp & - & - \\
\hline Spiraea hypericifolia & - & - & sol \\
\hline \multicolumn{4}{|c|}{ Herbs } \\
\hline Carex melanostachya Bieb. ex Willd. & $\mathrm{cop}_{3}$ & - & - \\
\hline $\begin{array}{l}\text { Phlomoides oreophila(Kar. \& Kir.) } \\
\text { Adyl., R. Kam. \& Machmedov }\end{array}$ & $\mathrm{sp}-\mathrm{cop}_{1}$ & $\mathrm{sp}$ & $\mathrm{sp}$ \\
\hline Agrimonia asiatica & $\mathrm{sp}$ & $\mathrm{sp}$ & $\mathrm{sp}$ \\
\hline Hypericum perforatum & sol-sp & $\mathrm{sp}$ & - \\
\hline Lavatera thuringiaca & sol & $\mathrm{sp}$ & - \\
\hline Urtica dioica & sol & sol & - \\
\hline Mentha asiatica Boriss. & sol-sp & - & - \\
\hline Filipendula ulmaria (L.) Maxim. & sol & - & - \\
\hline Nepeta pannonica & $\mathrm{sp}$ & $\operatorname{cop}_{1}$ & $\mathrm{sp}$ \\
\hline
\end{tabular}




\begin{tabular}{|c|c|c|c|}
\hline Geranium albiflorum & $\mathrm{sp}$ & - & - \\
\hline Fragaria viridis & $\mathrm{sp}$ & $\operatorname{cop}_{1}$ & sp-cop 1 \\
\hline Potentilla impolita Wahlenb. & sol & - & - \\
\hline Potentilla bifurca L. & sol-sp & - & - \\
\hline Potentilla asiatica & - & $\mathrm{sp}$ & - \\
\hline Potentilla soongarica Bunge & - & sol & - \\
\hline Calamagrostis epigeios (L.) Roth & sol-sp & sol & sol \\
\hline Poa pratensis & sol & - & - \\
\hline Elytrigia repens & sol & sp-cop ${ }_{1}$ & - \\
\hline Lactuca serriola $\mathrm{L}$. & sol & - & - \\
\hline Verbascum thapsus L. & sol & - & - \\
\hline Verbascum orientale & - & $\operatorname{cop}_{1}$ & sol-sp \\
\hline Inula helenium L. & sol & - & - \\
\hline Delphinium cheilanthum Fisch. & sol & - & - \\
\hline Inula britannica $\mathrm{L}$. & - & sol & - \\
\hline Salvia deserta & - & $\mathrm{sp}$ & $\mathrm{sp}$ \\
\hline Achillea millefolium & - & $\operatorname{cop}_{1}$ & $\mathrm{sp}$ \\
\hline Origanum vulgare & - & $\mathrm{sp}$ & $\mathrm{sp}$ \\
\hline Ziziphora clinopodioides & - & sp-cop 1 & $\mathrm{sp}$ \\
\hline Galium turkestanicum & - & $\mathrm{sp}$ & - \\
\hline Galium aparine & - & sol & - \\
\hline Medicago falcata & - & $\operatorname{cop}_{1}$ & sp-cop 1 \\
\hline Plantago major & - & sol & - \\
\hline Trifolium pratense & - & $\mathrm{cop}_{1}$ & - \\
\hline Amoria repens & - & $\mathrm{sp}$ & - \\
\hline Vicia cracca & - & $\mathrm{sp}$ & $\mathrm{sp}$ \\
\hline Thymus marschallianus & - & sol-sp & sol-sp \\
\hline Onopordum acanthium L. & - & sol & - \\
\hline Cichorium intybus L. & - & sol & - \\
\hline Convolvulus arvensis L. & & sol & \\
\hline Lathyrus pratensis & - & sol & - \\
\hline Veronica spuria & - & sol & - \\
\hline Polygonum aviculare L. & - & sol & - \\
\hline Artemisia absinthium & - & sol & - \\
\hline Rumex confertus & - & sol & - \\
\hline Geum rivale & - & sol & - \\
\hline Dactylis glomerata & - & $\mathrm{sp}$ & - \\
\hline Bromus japonicus & - & $\mathrm{sp}$ & sol-sp \\
\hline Bromopsis inermis & - & sol & $\mathrm{cop}_{1}$ \\
\hline Stipa capillata & - & - & $\mathrm{sp}$ \\
\hline Paeonia anomala & - & - & $\mathrm{sp}$ \\
\hline Leymus multicaulis & - & - & $\mathrm{sp}$ \\
\hline $\begin{array}{l}\text { Galatella angustissima (Tausch) } \\
\text { Novopokr. }\end{array}$ & - & - & $\mathrm{sp}$ \\
\hline Hieracium virosum & - & - & sol-sp \\
\hline Total: & 24 & 40 & 23 \\
\hline
\end{tabular}


The Tentek river with its tributary Orta Tentek pertains the Sassykkol lake basin. Study in the Orta Tentek river valley were conducted at elevation from 1594 to $1607 \mathrm{~m}$ a.s.l. The valley arboreal vegetation is formed by gallery woodland of birch (Betula tianschanica Rupr.) with sporadic Tien Shan spruce (Picea schrenkiana Fisch. \& C.A. Mey.) and willow (Salix triandra L.). The shrub layer includes Salix kirilowiana Stschegl., Myricaria bracteata. Swamp meadows are distributed in the river floodplain, steppe meadows are spread on the river terraces (Table 7).

Table 7. Species composition of meadows in the Orta Tentek river valley

\begin{tabular}{|c|c|c|}
\hline \multirow{3}{*}{ Species } & \multicolumn{2}{|c|}{ Abundance by Drude scale } \\
\hline & Steppe meadow & Swamp meadow \\
\hline & $1594 \mathrm{~m}$ a.s.l. & $1607 \mathrm{~m}$ a.s.l. \\
\hline \multicolumn{3}{|c|}{ Trees } \\
\hline Betula tianschanica & sol-sp & - \\
\hline Padus avium & sol & - \\
\hline Salix triandra & $\mathrm{sp}$ & \\
\hline \multicolumn{3}{|c|}{ Shrubs } \\
\hline Lonicera tatarica & sol & - \\
\hline \multicolumn{3}{|c|}{ Herbs } \\
\hline Festuca valesiaca & $\operatorname{cop}_{1}$ & - \\
\hline Sedum hybridum & $\mathrm{sp}$ & - \\
\hline Rumex confertus & $\mathrm{sp}$ & $\mathrm{sp}$ \\
\hline Phlomoides oreophila & $\mathrm{sp}$ & - \\
\hline Potentilla asiatica & $\mathrm{sp}$ & sol \\
\hline Gentiana kirilowii & sol & - \\
\hline Bupleurum aureum & sol & sol-sp \\
\hline Geranium collinum & sol & - \\
\hline Allium amblyophyllum Kar. \& Kir. & sol & $\operatorname{cop}_{1}$ \\
\hline Artemisia dracunculus & sol & - \\
\hline Achillea millefolium & $\mathrm{sp}$ & sp-cop 1 \\
\hline Fragaria viridis & $\mathrm{sp}$ & - \\
\hline Aconitum anthoroideum & sol & sol \\
\hline Phleum phleoides & sol & - \\
\hline Dianthus turkestanicus Preobr. & sol & - \\
\hline Dactylis glomerata & - & sp-cop 1 \\
\hline Deschampsia cespitosa (L.) Beauv. & - & cop $_{2-3}$ \\
\hline Ligularia macrophylla (Ledeb.) DC. & - & $\mathrm{sp}$ \\
\hline Vicia cracca & - & - \\
\hline Filipendula ulmaria & - & sol \\
\hline Thalictrum minus & - & $\mathrm{sp}-\mathrm{cop}_{1}$ \\
\hline Galium turkestanicum & - & sp-cop 1 \\
\hline Elytrigia repens & - & sp-cop 1 \\
\hline Lamium album $\mathrm{L}$. & - & sol \\
\hline Seseli schrenkianum & - & $\mathrm{sp}$ \\
\hline Agrostis gigantea Roth & - & sol-sp \\
\hline Elymus dahuricus & - & sol-sp \\
\hline Carex praecox Schreb. & - & $\operatorname{cop}_{1}$ \\
\hline Total: & 19 & 18 \\
\hline
\end{tabular}


The majority of rivers of the southern range (the Usek, Tyshkan, Khorgos, Borokhudzir, etc.) pertain to the Ile river basin. The Usek river is a tributary to the Ile river, the study comprised elevation points from 922 to $1225 \mathrm{~m}$ a.s.l. Swamp meadows in the river floodplain are formed by hygrophilous species (Typha angustifolia L., Rumex confertus, Mentha longifolia, Phragmites australis, Bistorta major S.F. Gray). Typical meadows are forb-grass (Elytrigia repens, Calamagrostis epigeios, Medicago lupulina, Polygonum aviculare, Plantago major, Cichorium intybus). Halophytic meadows are formed by Achnatherum splendens, Glycyrrhiza uralensis and by forbs (Salvia deserta, Melilotus officinalis (L.) Pall., Amoria hybrida (L.) C. Presl, Agrostis gigantea, Achillea millefolium). Meadow vegetation is impacted by grazing and recreation; meadows are usually disturbed moderately and severely. Weed and poisonous plant species serve as indicators of disturbance (Pseudosophora alopecuroides (L.) Sweet, Echium vulgare L., Dodartia orientalis L.).

In the Tyshkan river floodplain and on the river terraces, meadow vegetation and shrub thickets are distributed. In floodplain meadows clover species dominate (Amoria repens, A. fragifera (L.) Rskov, A. hybrida), forbs include Inula rhizocephala Schrenk, Medicago lupulina L., Mentha longifolia, Echium vulgare, Achillea millefolium, A. asiatica Serg., Taraxacum officinale Wigg., Verbascum songaricum Schrenk, Rumex pseudonatronatus (Borb.) Borb. ex Murb., etc. Shrub thickets are formed by Hippophae rhamnoides L., Trachomitum lancifolium, Myricaria bracteata, Berberis sphaerocarpa Kar. \& Kir. (Table 8).

Table 8. Species composition of meadows in the Tyshkan river valley

\begin{tabular}{|c|c|c|}
\hline \multirow{3}{*}{ Species } & \multicolumn{2}{|c|}{ Abundance by Drude scale } \\
\hline & Steppe meadow & $\begin{array}{l}\text { Flood plain forb } \\
\text { meadow }\end{array}$ \\
\hline & $1676 \mathrm{~m}$ a.s.l. & $1665 \mathrm{~m}$ a.s.1. \\
\hline \multicolumn{3}{|c|}{ Shrubs } \\
\hline Berberis sphaerocarpa & - & sol-sp \\
\hline Rosa acicularis Lindl. & - & sol-sp \\
\hline Hippophae rhamnoides & - & $\mathrm{sp}$ \\
\hline Trachomitum lancifolium & - & $\mathrm{sp}$ \\
\hline Myricaria bracteata & - & sol-sp \\
\hline \multicolumn{3}{|c|}{ Herbs } \\
\hline Festuca valesiaca & sol-sp & sol \\
\hline Bothriochloa ischaemum (L.) Keng & $\mathrm{sp}$ & - \\
\hline Nepeta pannonica & $\mathrm{sp}$ & - \\
\hline Stipa capillata & sol & - \\
\hline Salvia deserta & $\mathrm{sp}$ & - \\
\hline Potentilla impolita & sol & sol \\
\hline Achillea millefolium & sol & sol \\
\hline Achillea asiatica & - & sol \\
\hline Amoria hybrida & sol & $\mathrm{sp}$ \\
\hline Amoria repens & - & sp-cop 1 \\
\hline Amoria fragifera & - & sol-sp \\
\hline Melilotus officinalis & sol & - \\
\hline Elytrigia repens & $\mathrm{sp}$ & - \\
\hline Agrostis gigantea & sol & - \\
\hline Hypericum perforatum & $\mathrm{sp}$ & - \\
\hline Thymus marschallianus & sol-sp & - \\
\hline Geranium collinum & sol & - \\
\hline
\end{tabular}




\begin{tabular}{l|c|c}
\hline Phalaroides arundinacea & $\mathrm{sp}$ & - \\
\hline Poa stepposa & $\mathrm{sp}$ & - \\
\hline Galatella tatarica (Less.) Novopokr. & $\mathrm{sol}$ & - \\
\hline Berteroa incana (L.) DC. & sol & - \\
\hline Echium vulgare & $\mathrm{sol}$ & sol \\
\hline Ziziphora clinopodioides & sol & - \\
\hline Setaria viridis (L.) Beauv. & sol & - \\
\hline Artemisia dracunculus & sol & - \\
\hline Artemisia absinthium & - & sol \\
\hline Galium aparine & sol & - \\
\hline Centaurea squarrosa Willd. & sol & - \\
\hline Rumex confertus & sol & - \\
\hline Rumex pseudonatronatus & - & sol \\
\hline Elymus dahuricus & - & sol \\
\hline Achnatherum caragana (Trin.) Nevski & - & sol \\
\hline Medicago lupulina & - & sp \\
\hline Mentha longifolia & - & sol-sp \\
\hline Taraxacum officinale & - & sol \\
\hline Inula rhizocephala & - & sp \\
\hline Verbascum songaricum & - & sol \\
\hline Sisymbrium loeselii L. & - & sol \\
\hline Carex sp. & - & 24 \\
\hline Total: & 25 & \\
\hline & & cop \\
\hline
\end{tabular}

\section{Discussion}

Meadow vegetation of the Zhetysu Alatau Mountains is characterized by high species diversity and representativeness of valuable forage, pharmaceutical, honey, and other useful plants.

According to ecological-physiognomic classification, 6 vegetation types of meadows are found in the Zhetysu Alatau Mountains: halophytic on meadow-serozem saline soils, flood-plain-valley (forb-grass typical, grass-forb on floodplain meadow and meadow-chernozem soils; swamp meadows on paludal-meadow soils), steppe on meadow-chernozem and meadow-kastanozem soils, mid-mountain rich grass-forb on ordinary and leached chernozems, high-mountain subalpine on mountain-meadow subalpine turf soils, high-mountain alpine on mountain-meadow alpine turf soils.

Photos of the meadow types are shown in Appendix 2.

Halophytic meadows are formed on meadow-serozem saline soils with the shallow $(1.5-2.5 \mathrm{~m})$ groundwater table. The communities are mostly dominated by haloxeromesophilic species: grasses Achnatherum splendens, Aeluropus littoralis, Leymus divaricatus, L. angustus), licorice (Glycyrrhiza aspera, G. uralensis), and saltworts (Atriplex tatarica, Suaeda heterophylla, S. microphylla). Species composition of 100 sq. m sample plots varies from 11 to 15 plants.

Typical meadows (mesophytic) are formed on floodplain meadow soils with the groundwater level 1.5-3.0 m deep, under transient periodical flooding conditions. Meadows in the intermountain valleys are characterized by meadow-chernozem soils. The communities are mostly dominated by mesophilic and xeromesophilic species: grasses (Elytrigia repens, Bromopsis inermis, Phleum phleoides, Poa pratensis), forbs such as alfalfa (Medicago falcata, M. lupulina), clover (Amoria hybrida, A. repens, A. fragifera, Trifolium pratense), Achillea millefolium, Origanum vulgare, Agrimonia asiatica. Often typical steppe xerophytes (Stipa capillata, Festuca valesiaca) are 
presented. Indicators of anthropogenic impact are weed species (Lactuca serriola, Urtica dioica, Convolvulus arvensis, Artemisia absinthium, Polygonum aviculare, Onopordum acanthium). Species composition of sample plots varies from 11 to 40 plants.

Swamp meadows are formed on soils of the mire series with groundwater level 1.0$2.0 \mathrm{~m}$ deep, under the regular or periodical prolonged flooding conditions in floodplains and near springs (Ogar, 2003). The communities are mostly dominated by gygromesophilic species: sedge (Carex melanostachya, C. praecox), mint (Mentha longifolia, M. asiatica), Phragmites australis, Scirpus tabernaemontani, Filipendula ulmaria, Iris sogdiana. If the water supply is insufficient, abundance of mesophilic grasses (Elytrigia repens, Dactylis glomerata, Deschampsia cespitosa, Calamagrostis epigeios) increases. Species composition of sample plots varies from 13 to 24 plants.

Steppe meadows are formed on meadow-chernozem and meadow-kastanozem soils. The communities are mostly co-dominated by species of different life forms: xerophilic steppe bunch grasses (Stipa capillata, Festuca valesiaca, Poa stepposa), mesophilic, xeromesophilic and mesoxerophilic species (Bromopsis inermis, Elytrigia repens, Medicago falcata, Fragaria viridis, Achillea millefolium, Verbascum orientale, Thymus marschallianus, Nepeta pannonica, Salvia deserta). Species composition of sample plots varies from 7 to 25 plants. Indicators of anthropogenic impact are weed species (Berteroa incana, Echium vulgare, Setaria viridis, Centaurea squarrosa, Urtica cannabina).

Mid-mountain rich grass-forb meadows are formed on ordinary and leached chernozems in conditions of annual precipitation more than $800 \mathrm{~mm}$. The communities are mostly dominated by mesophilic species: grass (Dactylis glomerata), forbs (Achillea millefolium, Fragaria viridis, Origanum vulgare, Sanguisorba alpina, Lupinaster pentaphyllus, Thalictrum minus, Bunium setaceum). These meadows support a high diversity of typical mountain plants (Allium obliquum, Rhodiola linearifolia, Hieracium virosum, H. aurantiacum, Dianthus turkestanicus, Swertia connata, Eremurus tianshanicus, Gentiana kirilowii, etc.). Species composition of sample plots varies from 19 to 34 plants.

High-mountain mid-herb subalpine meadows are formed on mountain-meadow subalpine turf soils. The communities are dominated by mesophilic plants: forbs (Alchemilla sibirica, A. bungei, Geranium collinum, G. albiflorum, Aegopodium alpestre, Alfredia nivea, Potentilla gelida, etc.), grasses (Alopecurus pratensis, Poa pratensis, P. lipskyi, Phleum phleoides, etc.). Species composition of sample plots varies from 18 to 26 plants, in open aggregations of rocks and scree debris - 7-12 plants. Subalpine meadows are used for grazing. Overgrazing leads to increasing of weed and unpalatable plants such as: Alchemilla sibirica, Achillea millefolium, Urtica dioica, Berteroa incana, Plantago urvillei Opiz, Artemisia austriaca Jacq., Phlomoides oreophila.

High-mountain alpine meadows are formed on mountain-meadow alpine turf soils. Cryophytic low-herb meadows (Bistorta vivipara, B. elliptica, Primula algida, Festuca kryloviana, Poa alpina, Geranium saxatile, Trisetum altaicum, T. spicatum, etc.), kobresia-forb communities (Kobresia capilliformis, K. humilis, Alchemilla retropilosa, Leontopodium fedtschenkoanum), plant aggregations of rocks and scree debris (Dracocephalum imberbe, Saussurea glacialis, Rhodiola coccinea, Potentilla biflora, Oxygraphis glacialis, Trollius altaicus) are distributed there. Species composition of sample plots of low-herb meadows varies from 10 to 25 plants, in kobresia communities 
varies from 11 to 31 plants, in open aggregations of rocks and scree debris - 20-25 plants (Rubtsov, 1948).

Meadow vegetation is mostly used for grazing and haying. River valleys are frequently impacted by recreation, sometimes meadows are ploughed for sowing maize and sun-flower. The degree of human-induced degradation is assessed as moderate, with sites of severe degradation of plant cover.

Severe degree of grazing load results in valuable forage grasses being replaced by weeds, such as: Cichorium intybus, Dodartia orientalis, Pseudosophora alopecuroides, Urtica dioica, U. cannabina, Rumex confertus, Marrubium anisodon L., etc. In livestock stands and at cattle routes grow the following plant species: Urtica dioica, Artemisia absinthium, A. dracunculus, Heracleum dissectum, Leonurus glaucescens L., Angelica decurrens (Ledeb.) B. Fedtsch. Oftentimes the height of grass stand is rather great (120-170 cms), some plants reaching 2 meters. The grass stand of the Usek river valley abandoned fields is dominated by weed species Cichorium intybus, Echium vulgare, Avena fatua L., Convolvulus arvensis, Acroptilon repens (L.) DC., Lactuca serriola, Cannabis ruderalis Janisch., Cirsium arvense (L.) Scop., Conyza canadensis (L.) Cronq., Xanthium strumarium L., Berteroa incana, Setaria viridis, etc.

Permanent haymaking impact promotes changes of plant communities' structure, dominant composition, abundance and viability of species. Haymaking is conducted in the summit of efflorescence (maximal development) of the main dominant species. Haying does not allow those plant species to seed, to leave seed stock in soil. In this period propagate vegetative flexible species (grasses). As a result, forb communities very quickly become grass ones or with considerable participation of the latter. In addition, there occurs introduction of weed plants. (Catorci et al., 2016)

The short season of vegetation in the mountains creates certain difficulties in the use of natural hayfields. Since the plants develop and finish their growing season rapidly, all the haymaking activities have to be performed on a tight schedule. Untimely and delayed hay harvesting reduces the nutritional quality of hay and lessens forage weight. In delayed hay harvesting, grasses lodge, their stems are intertwined and it becomes difficult to perform machine harvesting. This is often observed in tall grass hayfields with prevailing Dactylis glomerata, Bromopsis inermis, Elytrigia repens, Medicago falcata, Onobrychis arenaria, etc. (Zotov et al, 1987).

\section{Conclusions}

The most diverse meadows are located in the northern range of the Zhetysu Alatau Mountains, meadow vegetation of the southern, more arid range is distributed in fragments, and steppes and shrubby thickets are spread in great areas (Dimeyeva et al., $2015 b)$. The reason is the different amount of annual precipitation.

Two State National Nature Parks cover a part of the Zhetysu Alatau Mountains, including areas with meadow vegetation. The "Zhongar Alatau" National Park is located in the northern range. There are widespread forb-grass typical, steppe, floodplain and high-mountain meadows, which could serve as a standard of undisturbed natural ecosystems. The National Park "Altyn Emel" is located in the southern range. Various types of halophytic meadows are presented here, with fragments of floodplain meadows. In the buffer zone of the national parks, meadows are used moderately.

The survey corroborated that the weak and moderate use of meadows is optimal to maintain a high diversity of species. This confirms intermediate disturbance hypothesis 
(Grime, 1973; Connell, 1978; Catorci, 2016, etc.). Meadows of the Zhetysu Alatau Mountains throughout a modern history have used to varying degrees, as pastures and hayfields, in dependence of types of meadows. Halophytic and swamp meadows are little used for grazing. The most valuable are forb-grass valley meadows.

Grazing leads to increasing in abundance of weed and unpalatable plants. Mowing leads to an increase in abundance of weeds, as well as forage species with rhizomes and reduction of forbs.

The national parks have zoning; the core area supports natural ecosystems. The creation of protected areas has allowed the meadows to recover after intensive grazing and mowing. However, there are signs of weak and sometimes moderate use. This is evidenced by species composition and abundance in the meadows some plants. Yarrow (Achillea millefoium) is typical natural component of meadows, its forage quality is low, and therefore, grazing leads to increasing of its abundance. It is especially abundant in valley and mid-mountain meadows. The same tendency can be observed with Alchemilla spp., especially in the subalpine zone.

Janišová (2014) notes that long-lasting intensive human influence, transformation of mesic grasslands to agricultural fields leads to uniform landscape structure. We have also seen sites with uniform community structure in abandoned fields dominated by Cichorium intybus, Avena fatua with patches of native and alien species (Elymus dahuricus, Bromus japonicus, Amoria hybrida, Cannabis ruderalis, Coniza canadensis, etc.). Overgrazed places show patchi vegetation cover - Artemisia dracunculus, A. absinthium, Urtica cannabina, Rumex confertus, and Pseudosophora alopecuroides dense aggregations inside meadows.

Acknowledgements. This work was facilitated by funding provided by the scientific-applied Program "Botanical Diversity of Crop Wild Relatives in Kazakhstan as a Source for the Enrichment and Conservation of Agrobiological Diversity Genetic Fund for the Implementation of the Food Program" (2013-2015) supported by Ministry of Education and Science of the Republic of Kazakhstan.

\section{REFERENCES}

[1] Bykov B. A. (1978): Geobotany. - Nauka, Alma-Ata.

[2] Bykov B. A. (1985): Spruce forests of the Tien Shan Mountains. - Nauka, Alma-Ata.

[3] Bykov B.A. (1973): Geobotanical dictionary. - Nauka, Alma-Ata.

[4] Caifeng Zh., Shujiang Ch., Yan L., Qi L., Xiang J., Jie D. (2013): Ecosystem Assessment of Xarxili Natural Reserve in Xinjiang. - Science and Technology Innovation Herald (10): 146-149.

[5] Catorci A., Tardella F. M., Piermarteri K., Pennesi R., Malatesta L., Corazza M., Scocco P. (2016): Effect of red deer grazing on alpine hay meadows: biodiversity and management implications. - Applied Ecology and Environmental Research 14 (2): 301318.

[6] Cherepanov S. K. (1995): Vascular plants of Russia and adjacent states (the former USSR). - Cambridge: University Press, New York.

[7] Chunlin M. (2008): The Study on Estimation of Vegetation NPP of Xiaerxili Nature Protection Area Based on RS. - Remote sensing technology and application 23 (3): 323327.

[8] Connell J. H. (1978): Diversity in tropical rain forests and coral reefs. - Science 199: $1302-1310$. 
[9] Denglera J., Janišová M., Török P., Wellsteinf C. (2014): Biodiversity of Palaearctic grasslands: a synthesis. - Agriculture, Ecosystems and Environment, 182: 1-14.

[10] Dimeyeva L. A, Ablaikhanov E. T. (2014): Peculiarities of vegetation altitudinal zonality in the southern range of the Junggar Alatau Mountains. - Bulletin of al-Farabi Kazakh National University, Ecology series 3 (42): 120-125.

[11] Dimeyeva L., Ablaikhanov E., Islamgulova A. (2015): Vegetation of the southern range of the Junggar Alatau Mountains. - In: Proceedings of Int. Conf. "Applied ecology: problems, innovations. - Tbilisi, Georgia.

[12] Dimeyeva L., Islamgulova A., Ablaikhanov E. (2015): Phytocoenotic characteristics of steppe vegetation in Junggar Alatau mountains. - In: Proceedings of VII Symposium "Steppes of Northern Eurasia". - Dimur, Orenburg.

[13] Drude O. (1913): Die Ökologie der Pflanzen. - Braunschweig.

[14] Dzhangaiev A M. (1977): Wild apple of Kazakhstan. - Nauka, Alma-Ata.

[15] Ellenberg H. (1973): Ökosystemforschung. - Springer-Verlag, Berlin.

[16] Ellenberg H., Mueller-Dombois D. (1967): Tentative physiognomic-ecological classification of plant formations of the Earth. Report SC/WS/269. - UNESCO, Paris.

[17] FAO (1997): Soils map of the world: revised legend. - Food and Agriculture Organization of the United Nations, Rome.

[18] Field Geobotany. (1959-1976): 1-5. - Nauka, Moscow-Leningrad.

[19] Flora of China: 1-25. Available from: http://www.efloras.org. Accessed July 2016

[20] Flora of Kazakhstan. (1956-1966): 1-9. - Nauka, Alma-Ata.

[21] Gao Y. H., Luo P., Wu N., Chen H., Wang G. X. (2008): Impacts of grazing intensity on nitrogen pools and nitrogen cycle in an alpine meadow on the Eastern Tibetan plateau. Applied Ecology and Environmental Research 6 (3): 69-79.

[22] Goloskokov V P. (1984): Flora of the Junggar Alatau. - Nauka, Alma-Ata.

[23] Grime, J. P. (1973): Competitive exclusion in herbaceous vegetation. - Nature 242: 344347.

[24] Gvozdetski N. A, Mikhailov N. I. (1978): Junggar Alatau. - In: Physical Geography of USSR. - Mysl, Moscow.

[25] Hai Ying, Yao Jianbao, Bingbujiafu, Yusufu Dilimulat, Zeng Yajuan. (2011): Study on the flora in Xiaerxili Nature Reserve in Xinjiang. - Arid Zone Research 28 (1): 98-103.

[26] Házi J., Penksza K., Bartha S., Hufnagel L., Tóth A., Gyuricza CS., Szentes SZ. (2012): Cut mowing and grazing effects with grey cattle on plant species composition in case of Pannon wet grasslands. - Applied Ecology and Environmental Research 10 (3): 223-231.

[27] Janišová M. (2014): The role of surrounding landscape in determining species richness of mesic grasslands in pannonian basin and carpathian mountains. - Applied Ecology and Environmental Research 12 (1): 251-266.

[28] Küchler A.W. (1949). A physiognomic classification of vegetation. - Annals of the American Association of Geographers, 39: 201-210.

[29] Küchler A.W. (1967): Vegetation Mapping. - Ronald Press, New York.

[30] Lipshits S. Yu. (1931): Vegetation of the Junggar Gate and Chulak plateau. - Bulletin of Moscow Sci. of Nat., Biol. series 11:1-2.

[31] Lvovich M I. (ed.). (1984): Water balance and water resources of the Northern range of the Junggar Alatau Mountains. - Nauka, Alma-Ata.

[32] Ma Chunlin. (2008): The Study on Estimation of Vegetation NPP of Xiaerxili Nature Protection Area Based on RS. - Remote sensing technology and application 23 (3): 323 327.

[33] Map of Vegetation of Kazakhstan and Middle Asia (desert region). (1995).

[34] Meadow grassland in the Kent Downs landscape. Available from: http://www.kentdowns.org.uk/uploads/documents/MEADOW_GRASSLAND.pdf. Accessed July 2016

[35] National Atlas of the Republic of Kazakhstan. (2010). Print-S, Almaty. 
[36] Novikova N. M. (1997): Principals of botanycal diversity conservation in deltaic valleys of the Turan lowland. Theses of Dr. of Sc. - Institute of Water Problems, Moscow.

[37] Ogar N. P. (1999): Vegetation of river valleys in semiarid and arid regions of contintal Asia. Theses of Dr. of Sc. - Institute of Botany and Phytointroduction, Almaty.

[38] Ogar N. P. (2003): Vegetation of river valleys. - In: Botanical Geography of Kazakhstan and Middle Asia (desert region). - Boston-Specter, St Petersburg.

[39] Polyakov P. P. (1941): Vegetation of Junggar Alatau Mountains in the area of the Sarkan and Baskan rivers. - Proceedings of Kazakh branch of USSSR AS. Geobotany serie. AS of SSSR, Moscow-Leningrad.

[40] Rachkovskaya E. I., Volkova E. A., Hramtsov V. N. (eds.) (2003): Botanical Geography of Kazakhstan and Middle Asia (desert region). - Boston-Specter, St Petersburg.

[41] Redecker B., Finck P., Härdtle W., Riecken U., Schröder E. (eds.) (2002): Pasture Landscapes and Nature Conservation. - Springer, Berlin.

[42] Reference Book on Climate of Kazakhstan. Air temperature. Almaty Oblast. (2004a). Kazhydromet, Almaty.

[43] Reference Book on Climate of Kazakhstan. Precipitation. Almaty Oblast. (2004b). Kazhydromet, Almaty.

[44] Relief of Kazakhstan (Explanatory text to Map of Geomorphology of KazSSR, 1:1500000). (1991). - Gylym, Almaty.

[45] Rodin L. E. (1933): Botanical-geographic review of the Lepsy region in the Junggar Alatau Mountains. - News of Geographic Society 65 (4): 296-319.

[46] Rubtsov N. I. (1948): Vegetation cover of the Junggar Alatau. - AS of KazSSR, AlmaAta.

[47] Semenov-Tienshanski P. P. (1947): Expedition to the Tien Shan Mountains in 1856-1857. Memories. - OGIZ, Moscow.

[48] Shipchinski N. V, Rodin L. E, Matveeva E. P. (1930): Vegetation cover of the Junggar Alatau Mountains. - AS of SSSR, Moscow-Leningrad.

[49] Sobolev L. N. (1960): Forage resources of Kazakhstan. - USSR AS, Moscow.

[50] Sokolov A.A., Pachikin K.M., Pachikina L.I. (1991): Soils and soil cover of the northern range of the Junggar Alatau mountains. - Gylym, Alma-Ata.

[51] Sokolov S. I, Assing I. A, Kurmangaliev A. B, Serpikov S. K. (1962): Soils of KazSSR. Almaty region. - Nauka, Alma-Ata.

[52] The Red Data Book of Kazakhstan. Plants. (2014). - Art Print, Almaty.

[53] Wang Xinzheng. (2007): Brief talk on resources evaluation and protection valve of Xiaerxili Nature Reserve in Xinjiang. - State Academy of Forestry Administration Journal (3): 45-49.

[54] Wild fruit forests of Kazakhstan: Problems of conservation and sustainable use of gene fund of global importance. (2012): Abstracts of Int. Conf. - Almaty.

[55] Xinzheng W. (2007): Brief talk on resources evaluation and protection valve of Xiaerxili Nature Reserve in Xinjiang. - State Academy of Forestry Administration Journal (3): 4549.

[56] Ying H., Jianbao Y., Bingbujiafu, Dilimulat Y., Yajuan Z. (2011): Study on the flora in Xiaerxili Nature Reserve in Xinjiang. - Arid Zone Research 28 (1): 98-103.

[57] Zhao Caifeng, Chen Shujiang, Liang Yan, Li Qi, Jia Xiang, Dang Jie. (2013a): Ecosystem Assessment of Xiaerxili Nature Reserve in Xinjiang. - Science and Technology Innovation Herald, (10): 146-149.

[58] Zhao Yang, Chen Shuijiang, Ma Jing, Huang Tiecheng. (2013b): Research on Wild Relative Plants in Xiaerxili Nature Reserve. - Science and Technology Innovation Herald, (10): 142-143.

[59] Zotov A. A, Sinkovski L. P, Shvan-Guriyski I. P. (1987): Mountain pastures and hay lands. - Agropromizdat, Moscow. 


\section{APPENDIX}

Appendix 1. List of sample areas

\begin{tabular}{|c|l|c|l|}
\hline $\mathrm{N}$ & \multicolumn{1}{|c|}{ Location } & Height (m a.s.l.) & \multicolumn{1}{|c|}{ Types of meadows } \\
\hline 1 & $\begin{array}{l}\text { foothills of the Altyn Emel } \\
\text { ridge: Mynbulak, Kolbastau, } \\
\text { Dongelekbastau springs }\end{array}$ & $680-732$ & $\begin{array}{l}\text { halophytic, } \\
\text { swamp }\end{array}$ \\
\hline 2 & $\begin{array}{l}\text { the head of the Borohudzir } \\
\text { river }\end{array}$ & $2257-2544$ & subalpine \\
\hline 3 & the Usek river valley & $922-1225$ & $\begin{array}{l}\text { swamp, } \\
\text { halophytic, } \\
\text { floodplain forb-grass }\end{array}$ \\
\hline 4 & the Tyshkan river valley & $1665-1676$ & $\begin{array}{l}\text { steppe, } \\
\text { floodplain forb }\end{array}$ \\
\hline 5 & the Zhalanash area & $975-1072$ & $\begin{array}{l}\text { swamp, } \\
\text { valley grass-forb, } \\
\text { steppe }\end{array}$ \\
\hline 6 & the Lepsy intermountain valley & $984-1071$ & $\begin{array}{l}\text { steppe, } \\
\text { valley forb-grass }\end{array}$ \\
\hline 7 & the Seghizbay pass & $1665-2200$ & $\begin{array}{l}\text { mid-mountain rich grass-forb, } \\
\text { subalpine }\end{array}$ \\
\hline 8 & the Orta Tentek river valley & $1594-1607$ & $\begin{array}{l}\text { swamp, } \\
\text { steppe }\end{array}$ \\
\hline
\end{tabular}

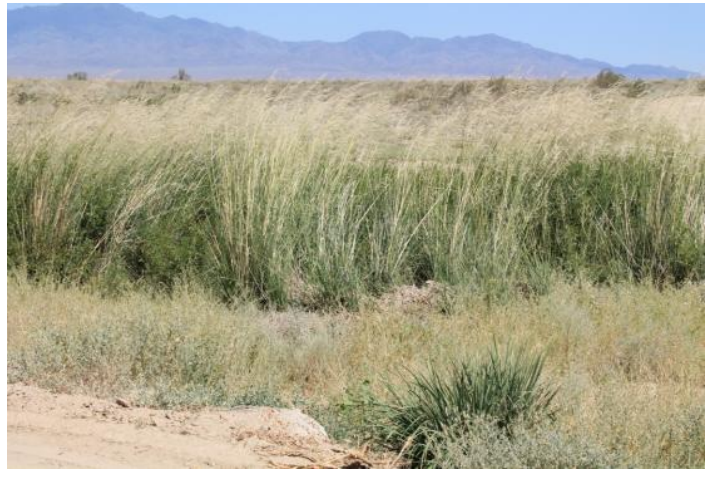

(a)

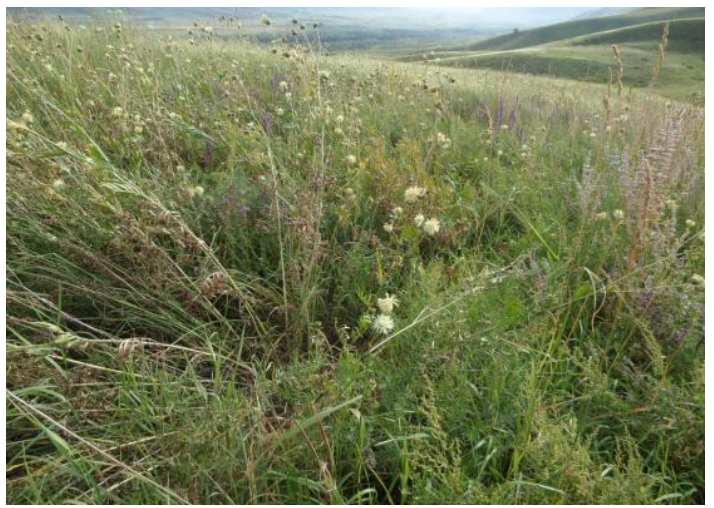

(c)

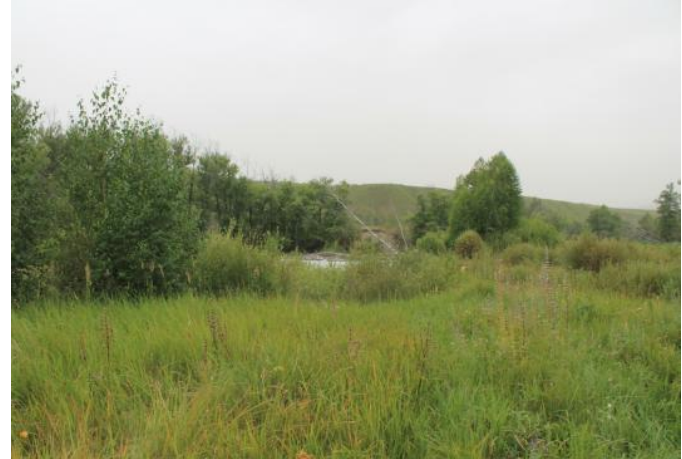

(b)

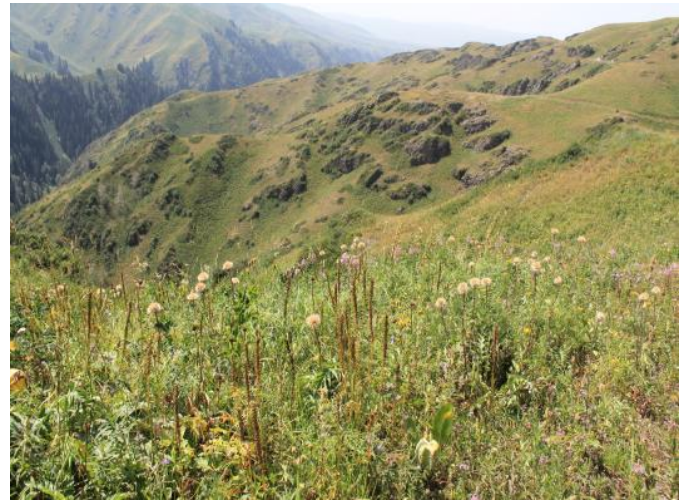

(d) 


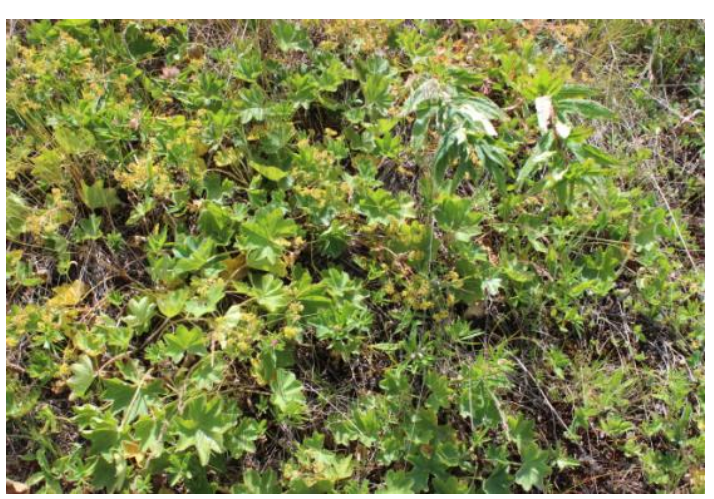

(e)

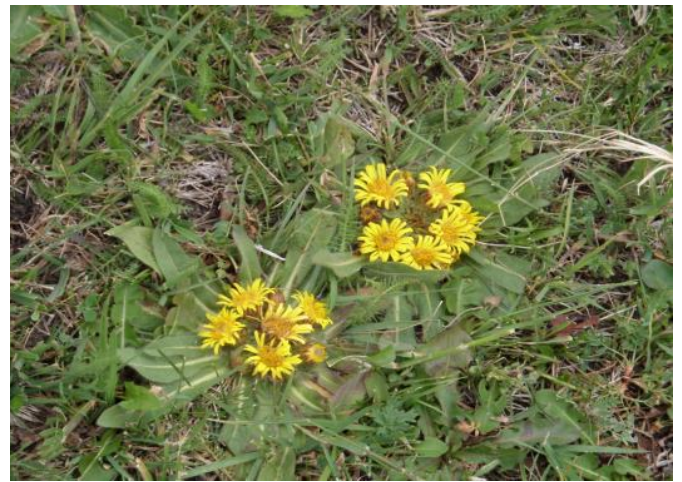

(f)

Appendix 2. Meadow types of the Zhetysu Alatau Mountains

(a) halophytic grass meadow (Achnatherum splendens, Atriplex tatarica, Iris sogdiana, etc.) in the foothills of the Altyn Emel ridge;

(b) swamp meadow (Carex melanostachya, Phlomoides oreophila, Nepeta pannonica, Calamagrostis epigeios, etc.) in the floodplain of the Aganakty river (Zhalanash area);

(c) steppe meadow (Centaurea ruthenica, Origanum vulgare, Salvia deserta, Stipa capillata, etc.) in the Lepsy intermountain valley;

(d) mid-mountain rich grass-forb meadow (Agrimonia asiatica, Stemmacantha carthamoides, Geranium collinum, etc.) in the Seghizbay pass;

(e) Alchemilla bungei subalpine meadow in the Seghizbay pass;

(f) Inula rhizocephala in the floodplain forb meadow of the Tyshkan river. 